\title{
POLITICAL ECONOMY AND TAX REFORM IN PARLIAMENT: SPAIN'S ATTEMPT TO IMPLEMENT INCOME TAX IN 1868-1869*
}

\author{
JAVIER SAN-JULIÁN-ARRUPE \\ Universitat de Barcelona $^{\text {a }}$
}

\begin{abstract}
The influence of economic ideas in parliamentary debates has attracted increasing attention in the analysis of the institutionalisation of political economy in the liberal age in the Western world. Within this framework, this paper explores a particular case: the relevance of economic ideas and the role of economists in the debates that took place in the Spanish Parliament in 1869 following the bill issued by the Minister of Finance Figuerola to establish a tax on personal incomes. Economic ideas and parliamentarian economists played a significant role in the design of the income tax as a key tool to modernise Spain's tax system, and in the subsequent parliamentary discussions.
\end{abstract}

Keywords: political economy, parliament, public finance, income tax, economic liberalism

JEL Code: A11, B12, H24, K34, N43

* Received 18 May 2010. Accepted 4 January 2011. I wish to thank José Luís Cardoso, Alfonso Herranz, Juan Zabalza and Anna Solé for their helpful comments on previous versions of this paper. I am also indebted to two anonymous referees for their extremely valuable remarks. Research has benefited from a research visit to the Instituto de Ciências Sociais da Universidade de Lisboa, under the supervision of José Luís Cardoso. Financial support has been supplied by the research project ECO2009-13331-C02-02 (Innovation and Science Ministry of Spain), the Group of Research in Globalization, Economic Inequality and Public Policy $(\mathrm{R}+\mathrm{D}+\mathrm{I}$ Reference Network in Economic and Public Policies, Generalitat de Catalunya), the Centre d'Estudis "Antoni de Capmany» d'Economia i Història Econòmica, and the Department of Economic History and Institutions of the Universitat de Barcelona.

a Departament d'Història i Institucions Econòmiques, Facultat d'Economia i Empresa, Universitat de Barcelona. Diagonal 690,08034, Barcelona, Spain. jsanjulian@ub.edu 


\section{RESUMEN}

El estudio de la influencia de las ideas económicas en los debates parlamentarios ha sido objeto de creciente atención en el análisis de los procesos de institucionalización de la economía política en la era liberal en el mundo occidental. Dentro de este marco, este ensayo analiza un caso particular: La relevancia de las ideas económicas y el papel de los economistas en los debates celebrados en las Cortes Constituyentes de 1869 acerca del proyecto de impuesto sobre la renta personal del ministro de Hacienda Figuerola. El pensamiento económico y los parlamentarios economistas jugaron un papel importante, tanto en el diseño del impuesto como medida de modernización del sistema fiscal español, como en los subsiguientes debates en el Legislativo.

Palabras clave: economia política, parlamento, hacienda, impuesto sobre la renta, liberalismo

\section{INTRODUCTION}

The process of penetration and diffusion of economic ideas in the political realm has recently become a major research area in the field of the institutional history of political economy. This concern is part of a broader research trend that explores how political economy became consolidated in the institutions and the culture of the ruling elites of the Western world in the liberal age (the second half of the $19^{\text {th }}$ century and first decades of the $20^{\text {th }}$ century). These studies follow the premise that analysing the institutional framework in which political economy develops and economists operate provides new insights leading to a better understanding of the evolution of economics (Coats 1993, p. 3). In this framework, the role of economists in political institutions, particularly in national parliaments, has attracted scholars' attention, seeking to assess the influence of economic ideas in the political debate and the design of economic policy. The performance of economists in the political sphere is indeed considered an essential part of the process of dissemination of economic ideas and of the institutional consolidation of economics (Augello and Guidi 2005a, 2005b, pp. xiii-xiv).

Although the issue of the connections between economics and politics is a core research area that has produced a substantial amount of studies, literature on the role of economic ideas in parliamentary debates is not plentiful. Some cases of the influence of economists and economic ideas in the British parliament in the $19^{\text {th }}$ century are known through the works by Fetter (1975, 1980), Gordon (1976), Grampp (1987), Luzstig (1995), Harris (1997), Gambles (1999) and Schonhardt-Bailey (2003, 2006). Recently, Italian 
scholars have developed extensive works on their national case (Augello and Guidi 2002, 2003, 2005a, 2005b). They have also broadened their initial geographical scope, leading an international project on economists in parliament in the liberal age in Europe, America and Japan (Augello and Guidi 2005a). Recently, Portuguese scholars have also shed light on their national case: Almodovar and Cardoso (2005), Cardoso (2007) and Bastien and Cardoso (2009). Regarding Spain, the presence of parliamentarian economists in the liberal age was reviewed by Almenar (2005), providing useful long-term insights into this phenomenon.

Within this institutional approach, this paper attempts to make a further contribution to this debate through the analysis of a case study. Specifically, I explore here the uses, relevance and influence of economic ideas in the debates that the Spanish Parliament held on the bill issued by the Finance Minister Laureano Figuerola in 1868, setting up a direct tax with the object of taxing personal income. Leaving aside some early precedents, this was the first attempt to implement an income tax in this country. I will analyse the economic arguments behind this tax project, the ideas sustained by supporters and detractors of the income tax, and the doctrinal influences on both parties. A comparison between this tax and the British income tax (a major topic in the debates) is also made. This case has some interesting characteristics: it took place in a revolutionary period during which Parliament became the core political institution, at a time in which liberal economic thought reached its peak in Spain. In this atmosphere, the role of economic ideas in lawmaking was relevant ${ }^{1}$. The income tax debate turned out to be very contentious, if compared to other discussions in Parliament during this period.

Using as primary sources mostly parliamentary records from the general assembly and from economic commissions, I will attempt to argue that economic ideas did play a crucial role in the bill's design process and in the ensuing debates. The Members of Parliament (MPs) taking part in the discussion had a good degree of competence in political economy, always in the framework of classical liberal doctrines. They also seemed to have extensive knowledge of foreign fiscal experiences, particularly the British income tax, which was regarded as a fiscal desideratum. The presence of parliamentarian economists in the Spanish legislative body at that time was extraordinary, if compared to the whole parliamentary era until 1922 (see Almenar 2005). This paper is organised as follows: the first section explains the new personal tax project; the second section explores the ensuing debates in Parliament; the third section considers the economic ideas that influenced MPs' lines of reasoning in the parliamentary process and the fourth section compares the establishment of the income tax in Britain with the Spanish attempt.

1 The importance of economic ideas in the performance of the economic team in office after the 1868 Revolution was already pointed out by Costas $(1982,1988)$. 


\section{FIGUEROLA'S PROJECT OF A PERSONAL TAX}

The September 1868 liberal revolution, which deposed Queen Isabel II, ushered in a political period in which a newly elected Parliament was intended to play a central role in the Spanish political process. Circumstances allowed a group of economists belonging to the liberal school of economic thought known as the Escuela economista to take control of the Ministry of Public Finance. Laureano Figuerola, the founder and chief representative of this school, was appointed Finance Minister in the provisional government formed in October $1868^{2}$. The Escuela economista is essential in our story. Its members, very cohesive from the doctrinal standpoint and extraordinarily committed to the diffusion of economic liberalism, were strongly influenced by French radical liberalism ${ }^{3}$. They favoured a certain degree of doctrinarism, and believed that liberal economic tenets were sufficient to foster economic growth and successfully manage public finance. Their main concern was economic freedom, particularly for trade, and they fought tenaciously for the reduction of Spanish customs duties ${ }^{4}$. Together with Figuerola, some other fellow economistas also entered the government, thus strengthening both its ideological lines and its liberalisation policies ${ }^{5}$.

Figuerola's appointment as Finance Minister granted him the opportunity to put into practice the economic programme of the Escuela economista, focused on the development of industrial capitalism and trade, mostly through liberalisation measures. This programme involved policies such as the encouragement of freedom of trade, industry, labour and credit; the restriction of government interventionism in industry; the transformation of indirect taxes into direct ones; the promotion of the creation of credit institutions, etc ${ }^{6}$. Figuerola's ultimate objective was to foster Spain's economic

2 Figuerola has been studied by many scholars; however, we still lack a complete biography. Recent works have been delivered by Costas (1982, 1988), Cabrillo (2000), Jané Solà (2003), Román (2003), Perdices et al. (2003) and Estapé (2006).

${ }^{3}$ In fact, the introduction of French economic liberalism in Spain, first through J. B. Say's works, and later through his most radical followers (especially Bastiat, highly praised by the economistas), marked the doctrinal evolution of Spanish political economy in the $19^{\text {th }}$ century. See Almenar (2000), Almenar and Lluch (2000) and Serrano et al. (2001).

4 The Escuela economista can be considered as the Spanish version of the Manchester School or the French Optimistic School. They founded some journals and societies in order to diffuse their ideas; particularly important would be the Asociación para la Reforma del Arancel de Aduanas (1859), with the aim of lobbying to reduce tariffs. Their faith in political economy as the science of government, as became apparent in the parliamentary debate, was exceptional (see Costas 2000 and Román 2003).

5 The members of the Escuela Rodríguez, Sanromá, Bona and Ruiz Gómez were in office and Pastor and Gimeno Agius collaborated with Figuerola. According to Fetter (1980, p. 232), a strong presence of economists in the government was an exception in Europe in the $19^{\text {th }}$ century. The Spanish case at that time should also be regarded as such.

6 According to Costas (1988, pp. 39-40; 1982, pp. 638-639), the main political forces behind the Revolution agreed to it. 
growth in the long term. His strategy was a gradual reformism, which gave priority to economic and fiscal structural reforms. This would increase public revenues in the long term, but implied resorting to credit in the short term, temporarily boosting public debt (Costas 1988, pp. 60-63; his decision not to tackle the problem of the budget deficit immediately would cause him many difficulties in Parliament). Concerning taxation, Figuerola's main actions were an essential reduction in customs duties, the abolition of taxes on consumption and the establishment of a tax on incomes.

On October 12, 1868, the provisional government issued the decree of suppression of consumption taxes and their replacement with a new personal $\operatorname{tax}^{7}$. In fact, the abolition of that levy was the acknowledgement of a de facto situation, as they had already been eradicated by the local revolutionary juntas formed during the revolutionary process. Although Figuerola was not in favour of consumption taxes, he was not pleased with this radical measure, as it was against his gradualist strategy: he would surely have preferred not to remove any fiscal revenue before having an actual replacement (Costas 1988, pp. $79-80)^{8}$. The financial viability of the Revolution made it impossible to dispense with any source of revenues without seeking a new one, or without dramatically cutting expenses, as Treasury circumstances did not allow for tax relief. Therefore, Figuerola devised a new direct personal tax, named repartimiento personal. It was levied on «individual wealth» through two indirect indicators: rent paid for housing and the number of members of the household. It was proportional, although tax relief was allowed to large families. The allocation of the tax burden was made using taxpayers' personal statements. However, the procedure to calculate the eventual tax debt turned out to be quite complex ${ }^{9}$. The participation of taxpayers was sought, in the British fashion, both to allocate the tax burden and to supervise complaints. According to the project of public budget for 1869-1870, its revenues should amount to 150 million reales (around 7 per cent of all public revenues, and approximately 25 per cent less than what consumption taxes had yielded the previous year).

\footnotetext{
7 Consumption taxes were set up in the tax reform of 1845. They were initially charged on wine, beer, cider and liquors, meat, olive oil and soap. They constituted a major source of finance for local administrations González de la Peña (1891, pp. 268-270). See Figuerola's 12 October decree in the Diario de Sesiones de las Cortes Constituyentes 1869-1871 - from now on DSCC - (12, Appendix).

8 Set the probable hypothesis that Figuerola was forced to accept it in order to avoid popular riots. However, he also rejected some further reforms that the juntas had made on their own concerning tariffs.

9 According to the project, the resulting tax bill was corrected by a factor accounting for the size of the taxpayer's town, in order to reflect the effect of diverse price levels. However, there was a system of quotas that caused distortions. The government set a quota corresponding to the personal tax to every town, which would then be distributed among local taxpayers by the town council and a board of taxpayers. This favoured fiscal fraud, which politicians of the Revolution claimed to fight. The actual taxpayer was the head of the family, who was responsible for the payment of the shares of all the members of his family above 14 years of age, including servants. Local councils, much of whose finance used to be provided by consumption taxes, were allowed to add a surcharge to the tax fee, plus another 8 per cent for collection expenses (DSCC 12, Appendix, pp. 41-52).
} 
With this tax, Figuerola was attempting to tax individual income (which he considered to be the correct indicator of the ability to pay), taking housing expenditure as a good indicator of income. Was it his ultimate aim to introduce the seeds of a general personal income tax in Spain? ${ }^{10}$ This would seem to be the case. According to the tax decree and his interventions in Parliament, Figuerola expected the personal tax to be the main instrument in the transformation of the direct tax structure. He planned to extend it so that it would become one of the main sources of Treasury revenues in the long term, by gradually converting all direct taxes into the personal income tax, making it the cornerstone of a modern liberal tax system. In Parliament, Figuerola supported the doctrine of the single tax on incomes as the fiscal ideal. His tax project was the instrument to achieve it: «I wish I could influence MPs' will, and from this moment on, turn all the Spanish land taxation into a personal tax ${ }^{11}$. He contended that public revenues were the key to the economic regeneration of Spain. It was necessary to liberalise them steadily and to introduce a tax on incomes, which would operate as a major device to foster economic development and remove the obstacles to economic circulation ${ }^{12}$.

Figuerola made sure that his tax was scientifically designed; that is, in line with the principles of political economy. The tax decree underlined that the personal tax project was «in accordance with sound financial doctrines»: it was a direct tax, general, equitable, certain and clear (every taxpayer knew how much he had to pay), inexpensive in its administration and collection, easy (average tax rates were low) and flexible, as it was possible to adapt the tax to the nation's increases in population and wealth. Therefore, the new tax was based on the classical liberal principles of taxation as enunciated by Smith and J. B. Say, and reproduced by the main Spanish economists of the century. From the doctrinal point of view, it was perfectly acceptable and justified. By following these scientific economic principles, the decree assured that the personal tax would result in freedom of circulation and trade, better supplied markets and would increase national welfare ${ }^{13}$.

The doctrinal principles of personalisation and generality were particularly important to Figuerola. He believed that the principle of personalisation should become one of the milestones of the renewal of the Spanish fiscal system $^{14}$. Taxes should be personal (unlike the main Spanish direct taxes the land tax and the tax on industrial and trade returns - which were product taxes), because they were essentially a reciprocal exchange for the

${ }^{10}$ A single direct contribution was an old liberal fiscal aspiration. Mateo del Peral (1974, pp. 15-16).

${ }_{11}^{11} \operatorname{DSCC}(23$, p. $414 ; 105$, pp. 2883-2884).

12 DSCC (105, p. 2887).

${ }^{13}$ In opposition, former consumption taxes were «contrary to freedom, opposed to economics and harmful to the maximum extent to public wealth» (DSCC 12, Appendix, p. 39).

${ }^{14}$ DSCC (105, p. 2884). 
services supplied by the state to the individual, which allowed him to devote his time to his business freely and safely. The new tax brought a noteworthy innovation to the fiscal system as it introduced this principle of personalisation in a major tax ${ }^{15}$. The principle of generality, "the only sign of justice that we can identify in consumption taxes» ${ }^{16}$, was also crucial, because it would encourage a taxpaying culture in Spain. All individuals should pay tributes to finance state services according to their ability and for the sake of justice $^{17}$. The principle of flexibility was another essential feature of the new tax, as it would make it possible to overcome one of the main problems of the Spanish product taxation system ${ }^{18}$. It was designed to be adaptable to changes in national economic growth, which is why Figuerola expected its yields to increase progressively ${ }^{19}$.

The example to follow was that of the British income tax. Figuerola was convinced that his personal tax, by leading Spanish finance towards an income tax, would be crucial for the economic prosperity of the country, as had been the case in Britain ${ }^{20}$. Figuerola explicitly sustained that his personal tax was directly inspired by the British income tax, the decisive tool that had allowed a «magnificent» transformation in the public budget of this nation, supplying the state with enough revenues without charging taxpayers much. He also praised the British fiscal culture, which was in turn responsible for the success of the income $\operatorname{tax}^{21}$. As previously mentioned, Figuerola assumed that the healing of the Spanish economy depended on the gradual transformation of public revenues. This had happened in Britain, thanks to income tax:

«The revolutionary moment of Spain lies in a change in the system. Public incomes have to be changed during six or eight years, because I do not think it is possible to improvise or present a new system in a period of two or three years. The economic revolution in Britain

15 The structure of the Spanish fiscal system was grounded on the general principle of product taxation and complemented with some indirect taxes, following the French model. This structure was the outcome of the Mon-Santillán reform in 1845. This system had two major flaws: its limited collecting capacity and its inability to follow GDP growth (see Fuentes Quintana 1990, pp. 4-47, Estapé 2001 and Artola 1986). A good summary of the Spanish fiscal history in the $19^{\text {th }}$ century can be found in Comín (2010).

16 DSCC (12, Appendix, pp. 40-41). Regarding generality, the personal tax set up some exceptions, a fact that would bring Figuerola much criticism.

17 DSCC (105, pp. 2883-2884).

18 DSCC (12, Appendix, pp. 40-41).

19 DSCC (23, pp. 414-415; 105, pp. 2883-2884). Figuerola announced in the Chamber that the revenues supplied by the personal tax would allow the abolition of the public monopoly of salt in the following fiscal year.

20 DSCC (12, Appendix, p. 40).

21 Figuerola even asserted that British income tax suffered from infinitely larger flaws than his personal tax, but that they had been overcome thanks to this excellent fiscal culture DSCC (23, pp. 414-415). 
has been carried out slowly, steadily, and in order to do so a special contribution was established, the income tax» 22 .

\section{THE PERSONAL TAX DEBATE IN PARLIAMENT}

Despite Figuerola's efforts to publicise the advantages of his project, and his pledge to eliminate its possible flaws, the new personal tax was not welcomed, mostly because public opinion had assumed that the abolition of consumption taxes would not be offset by a new levy. The new personal tax had been enforced since the end of 1868 by the provisional government decree, but it had to be sanctioned by the new Constituent Assembly formed after the elections in January 1869 , in which the coalition of parties supporting the government held a majority ${ }^{23}$. Despite the fact that the new personal tax meant quite a modest fraction of public revenues, it turned out to be a very controversial matter. According to the parliamentary procedures, prior to the debate in the general assembly, every item in the budget project had to be examined by the parliamentary Commission of Public Budget and Sub-Commission of Public Revenues, in charge of issuing a report, which would later be discussed and voted in the assembly. Virtually all MPs specializing in political economy formed part of the commissions.

There are no records of the debates in these commissions; however, it is possible to infer that they were tough. Figuerola (not a member of the commissions himself) felt constrained to take part in the meetings in order to influence commissioners to pass his project. After deliberation, the Budget Commission decided to introduce some substantial amendments in Figuerola's $\operatorname{tax}^{24}$ : The personal tax survived, but it had suffered fundamental changes. It had in fact become a pure direct tax on personal income. As in Figuerola's scheme, every citizen over 14 years of age was liable to the tax. The settlement of the tax burden would be made in proportion to the income of every individual, assessed through taxpayers' individual statements of income ${ }^{25}$. The Administration would survey individual tax returns and taxpayers would

22 DSCC (105, p. 2887)

23 The outcome of the 1869 elections was as follows: Progressive Party, 160 seats; Unión Liberal, 80; Democratic Party, 40; Republicans, 85; Absolutists, 20; others, 11. The provisional government was formed by members of the Progressive Party and the Unión Liberal. Together with the democrats, these three groups formed the parliamentarian majority that backed the government.

${ }^{24}$ On the debates of the commissions, see San Julián (2008, pp. 100-105).

25 Again, the procedure to calculate the individual tax bill was quite complicated. The government would assign each province its corresponding quota, which would in turn be distributed among towns by provincial councils. Local councils would allocate the final bills to individual taxpayers. Councils might impose surcharges on the tax bill in order to obtain revenues to finance their activities. The maximum surcharges allowed were 25 per cent for local authorities, 30 per cent for provincial governments and another 6 per cent to meet collecting expenses. As in the previous model, the head of the household was responsible for the payment of the shares of his wife and progeny (DSCC 104, Appendix 1, p. 10). 
participate in the management of complaints. Theoretically, these bases rendered the tax much fairer and more precise than Figuerola's model, but obviously posed overwhelming difficulties if the tax were to be implemented in an acceptable and reliable way. Individual statements of wealth were impossible to check by the scarcely equipped fiscal authorities, leaving much scope for fiscal fraud. Figuerola's bases were questionable, but probably more practicable. According to the report text, the flood of complaints from local councils made the reform of the income tax absolutely necessary (this was the only item of the budget in which major changes were introduced, which shows the dissensions within the parliamentary majority). Figuerola had no alternative but to accept the new bases (he defended them in the chamber), in order to save the project of setting up an income tax in Spain.

The ensuing debate in Parliament, therefore, centred on this new income tax project, although to the primitive tax planned by Figuerola changes were made constantly. Several features of this debate can be highlighted: Parliamentarian economists shared a common view of fiscal principles, grounded in economic liberalism, which none of them questioned: minimum state, budget equilibrium, efficiency and equity in taxation, preference for direct taxes over indirect, and also the convenience of taxing incomes. As a result, the discussion lay mostly in the convenience and possibility of implementing such a tax in Spain. The government faction supported it directly as an important piece of political economy. The opposition favoured the idea that principles should be applied only taking into consideration the particular characteristics of the territory. It was also a debate between long- and shortterm economics. Figuerola justified the income tax (and the entire public budget) on the basis of a long-term economic reconstruction, which required new deficits, but would render its outcomes in some years. The opposition's only alternative was the immediate restoration of Spanish credit, cutting expenditure and not increasing taxes in order to balance the budget and disdaining any long-term economic strategy. Another issue pervaded the debate (as it did others too): the discussion on the eventual form that the Spanish state would have after the Revolution, bringing monarchists face to face with republicans (the latter blamed the Monarchy for the budget deficits and demanded radical cuts in spending).

MPs who defended the new income tax in the debate (mainly the spokesmen of the Budget Commission) used Figuerola's lines of reasoning already outlined in the decree of 12 October, as they served equally for the new version of the tax. Some arguments were particularly highlighted. The idea of income tax as an instrument to foster economic growth was one of them: Herreros de Tejada, MP of the Escuela economista, stated that the ultimate goal of the fiscal reforms proposed by the government was to increase national product and trade, which would render larger public revenues in the long term. Supporting the economistas' idea that only a liberal 
framework could ensure economic growth, he sustained that liberalism was the driving force behind the new personal $\operatorname{tax}^{26}$. Liberal economic doctrine provided powerful arguments to support the income tax; specifically, the idea that a single tax on incomes was the scientific ideal to build a national modern taxation system. Many MPs mentioned this idea in the debate (both to support the income tax project, and also to attack it, invoking its difficulties). Among those who defended the income tax based on this idea, Ruiz Zorrilla, the Minister of Public Works, stated that the personal income tax was a genuine attempt to gradually introduce a single tax in Spain, the ideal of taxation theory ${ }^{27}$. Herreros de Tejada described the single tax as the "political economy desideratum», forecasting that, once stabilised and accepted, the income tax would be the first step towards the transformation of all taxes into a single tax in Spain. Baeza, MP, also referred to the single tax as «the beautiful ideal of modern economic science» ${ }^{28}$. The soundness of the technical design of the income tax was also invoked. Cancio Villamil, MP, highlighted the convenience of the bases of the tax: «generality and proportionality of quota». On the one hand, taxpayers should pay in proportion to their income, and on the other hand, all citizens should pay as much as they could, in exchange for the services supplied by the state ${ }^{29}$. The last main line of reasoning was the British example. Defenders of the income tax tried to highlight its similarities with the British income tax, which had become legendary, the balm capable of solving the financial troubles of the country. Herreros de Tejada believed that the project would have the same "wonderful» effects that income tax had had in Britain. In spite of the differences regarding fiscal culture between the two countries, he claimed: "What is so good in England, why should it be so bad in Spain?» ${ }^{30}$. Figuerola himself also intervened ardently in the debate supporting the new bases of

26 The Commission's declared aim was «to remove obstacles to production, in order to, instead of increasing taxes, obtain larger revenues, larger taxable bases, through the development of the living forces of the country». This is because «the Commission professes liberal principles $[\ldots]$ and, above all, concerning ideas on public administration, it perfectly agrees with the most radical ones» (DSCC 110, p. 3146).

27 "I believe that the aspiration of every individual devoted to economic matters is the single tax [...] the personal tax would be a test of the single tax in our country». In his opinion, all taxes that Spanish citizens were currently paying could be replaced by the new personal tax, the ideal of economic scientists. To achieve this target, it was necessary to start gradually, with limited tax rates. This was Figuerola's strategy (DSCC 108, pp. 3040-3043).

28 DSCC (110, pp. 3146-3151). During the parliamentary procedure, Baeza changed his vote. He first voted against Figuerola's tax in order to open a debate that would reconcile the public's complaints «with the principles of the economic science and the doctrines of liberalism proclaimed by the September revolution" in order to settle the bases of the income tax. He calculated that there were around three million taxpayers in Spain, and with the personal tax, the figure would rise to around nine million individuals, which explained the people's opposition (DSCC 110, p. 3159).

${ }^{29}$ DSCC (108, p. 3156). Cancio was adhering to one of Figuerola's main ideas: everybody should contribute to the expenses of the state. The idea of generality caused great controversy, for many MPs, particularly Republicans, did not think that the poor should be subject to taxation.

$30 \operatorname{DSCC}(108$, p. 3150). 
the tax (mentioning its vagueness and forecasting its practical difficulties). Although he believed his proposal was far better, at least the new income tax preserved the essential principles of generality and personalisation, in his opinion crucial in the fiscal modernisation of Spain ${ }^{31}$.

The MPs who opposed the new tax started by questioning its legitimacy. Consumption taxes had been abolished during the Revolution and should not be replaced with any other tax. Besides, the income tax was the consequence of an excess in public expenditure, inherited from pre-revolutionary cabinets, which the provisional government had not been able to cut. Focusing on the income tax itself, they did not question its theoretical soundness: most, if not all, opposition MPs acknowledged that a single tax on personal incomes was the scientific ideal expressed by classical liberal authors. However, they saw it as a chimera, impossible to establish in Spain. Republican MP Tutau, the most highly qualified economist in the opposition, supported the need for an income tax in Spain, but disagreed with the bases of the projected income tax. He foresaw the immense difficulties the administration would have in collecting the tax and was very pessimistic about its success ${ }^{32}$. Herrero, MP, a dissident member of the majority and one of the strictest opponents of the new tax, believed that the ideal of taxation theory was the single tax, be it on capital or on income, but tax fraud and the lack of resources of the fiscal administration to control individual assessments meant that it was not advisable for Spain ${ }^{33}$. Time would prove both MPs right. A major argument against the new tax was to underline its differences with the British income tax. Its performance was quite well known by some of the MPs, British fiscal organisation was praised as the most modern in Europe, and the tax culture of British citizens was admired. All this, some MPs assured, meant that it was impossible for a similar income tax to succeed in Spain, or at least to attain the positive effects it had had on British economic growth. Republican MPs especially pointed out their differences in fairness: Orense, MP, claimed that there was no tax threshold for low incomes in the Spanish project and the method of allocation through quotas prevented real proportionality. Garrido,

31 Regarding its application, he acknowledged that the system for setting the individual liabilities in the new bases was similar to the British income tax. In any case, Figuerola maintained that the original bases of his project were easier to manage than the new ones proposed by the Commission (DSCC 110, pp. 3161-3162). In fact, opposition in Parliament attacked Figuerola's tax questioning its appropriateness, fairness and legitimacy. Besides, the new tax was criticised because of its impracticability.

32 Tutau believed that the income tax bases should be wider, also taxing yields from public bonds and public officials' earnings. He considered that the true idea of the income tax was adopted in Figuerola's first tax proposal, not in the Commission's version (DSCC 108, pp. 3033-3038). Tutau defended a decentralised tax system in which the revenues of the state were only customs duties and the income tax (DSCC 105, p. 2868). One of his arguments in favour of the income tax was that in Austria, where a tax of this kind had been set up, public debt bonds had increased their price (DSCC 105, p. 2871).

${ }^{33}$ DSCC (107, pp. 2997-3003). 
MP, a socialist republican, also insisted on the issue of the threshold: the income tax should be paid only by those able to contribute, as was the case in Britain ${ }^{34}$. However, the main criticism came on the issue of technical differences: Tutau, despite being an admirer of the British income tax, voted against the personal tax because he believed that the project had numerous flaws when compared to its British model ${ }^{35}$. The issue of the individual assessment of income that was apparently working well in Britain was the most controversial basis of the new income tax project. The risk of massive fraud, the administrative impossibility to check taxpayers' returns and the lack of reliable data on national taxable bases seemed to be insuperable problems.

What was the degree of expertise in political economy of the MPs taking part in the debate on the personal tax? Following their interventions in Parliament, it seems that they had sound knowledge of economic principles (in the framework of classical liberal paradigm), and of the fiscal policies developed by more advanced European countries. Active participation in the income tax debate required at least a minimum qualification in fiscal issues, for the discussion sometimes involved technical aspects that, if not of great difficulty, required some familiarity with taxation questions. Naturally, the economic substance of their interventions varied; some MPs made remarks of a political, even demagogic, nature, whereas others showed fiscal competence. No doubt, some doctrinal statements in the debate were merely instrumental. The discussion on who can be considered a parliamentarian economist in the liberal age is open. Augello and Guidi (2003, pp. xxii-xxvii) have adopted two objective criteria issued by Fetter (1980, pp. 12-13), namely "profession» and "authorship», adding three more subjective criteria: self-consciousness, behaviour in parliament and public recognition of the status of economist. Following these criteria, the list of Spanish MPs with a significant degree of expertise in political economy at that time could perhaps include around fifteen names, a circumstance that would not be matched in the rest of the liberal age ${ }^{36}$. The expertise of some MPs is indubitable; this was the case of economic professors (Figuerola, Moret, Rodríguez and Echegaray), or civil servants with major experience in economic posts. The competence of others probably demands more in-depth assessment,

${ }^{34}$ DSCC (110, pp. 3139-3146). Garrido believed that the issue of the personal tax was a «purely political issue; not a purely economic issue: A new tax is a very difficult issue that leads to contempt and protest, and a new tax discredited governments» (DSCC 110, pp. 3154-3156).

${ }^{35}$ DSCC (108, p. 3034). It seems that Tutau's vote was mostly influenced by the Republican Party.

36 Following Augello and Guidi, it is possible to consider as parliamentarian economists at least Figuerola, Rodríguez, Echegaray, Moret, Herreros de Tejada, Tutau, Cantero, Ardanaz, Ruiz Gómez, Capdepón, Gimeno Agius, Cancio Villamil, Herrero. Pastor, Sanromá and Madrazo, notable liberal economists, did not take part in the debates, but belonged to the Parliament at that time. Republicans by Pi i Margall, Orense and Garrido seemed to have had acceptable knowledge of political economy too. 
although evidence from their background, professional activities and parliamentary discourses seems to suggest some competence ${ }^{37}$.

The position of the majority of these MPs who were economic specialists was to support government policy - therefore the income tax - as an accurate tool to modernise the Spanish tax system. However, not all of them backed Figuerola's original project, as seen in the commissions. Others maintained a relativist position, accepting the income tax doctrine, but rejecting it for Spain because of the country's economic and fiscal structure (no doubt, their parties' positions marked the orientation of their final votes). The tax reform found most support among MPs who were members and sympathisers of the Economist School. Three of its most renowned representatives, Echegaray, Moret and Rodríguez, addressed a document to the Chamber contending that one of the keys for the economic regeneration of Spain was an increase in public revenues, which demanded taxing sources of incomes that had so far remained untaxed, especially yields on financial assets. In their opinion, this called for a general income tax in Spain, following the British income $\operatorname{tax}^{38}$. As previously mentioned, behind Figuerola's plan to reform the tax structure, there was an enthusiastic confidence in political economy as a science of government. The economistas were very keen, profiting from the opportunity furnished by the new Parliament, to put across their doctrines and faith in economic science. Figuerola, in the tax decree, had stated that the characteristics of his personal tax fitted well with the new era opened by the Revolution: the era in which scientific political economy, rather than arbitrariness, should rule national finance ${ }^{39}$. In the debate, Ruiz Gómez, MP, from Figuerola's team in the Ministry, also stated that the science of public finance should guide the fiscal system of the country ${ }^{40}$. Echegaray, Moret and Rodríguez, in the aforementioned document, also proclaimed an outstanding optimism in economic liberalism and parliamentary democracy as key factors for Spain's economic progress: «Spain will prove

37 Data on many of these MPs are scarce. Gimeno, Ruiz Gómez, Capdepón and Cancio had occupied several posts as secretaries and sub-secretaries in the Finance Ministry. Cantero was the former governor of the Bank of Spain. Ardanaz and Tutau would become finance ministers in 1869 and 1873, respectively. Herreros de Tejada took mercantile studies and was the secretary of the Asociación para la Reforma del Arancel de Aduanas (see Llanta 1869).

38 DSCC (105, Appendix 1, pp. 1-3). This document, which is a dissenting vote issued after the Budget Commission passed the new bases of the income tax, is odd. In it, these MPs suggested that the government should devise a new tax capable of collecting at least half of the budget deficit predicted. They were probably referring to an income tax of a much larger scope than the projected tax. However, according to the Commission's records, it seems that Moret played a major role in the drafting of the Commission's new bases of the personal tax (Archivo Congreso Diputados, Serie General, leg. 144, n.2, pp. 12-13).

$39 \operatorname{DSCC}$ (12, Appendix, p. 41).

40 Ruiz Gómez regretted that Spanish universities were not used to teaching the science of taxation, "the good application of public incomes, making public expenditure productive», which guided the fiscal systems of the most advanced countries (DSCC 105, pp. 2859-2860). 
that freedom and individual initiative are the only true origin of wealth, morality and progress» ${ }^{41}$.

The personal tax debate was the longest on economic matters that the Constituent Assembly held in 1869. Eventually, and despite last minute movements of the opposition trying to block the final vote, the personal tax with the new bases of the Budget Commission was passed ${ }^{42}$. However, those who forecasted difficulties for the income tax in Spain were right; the revenues it supplied quickly fell and it was suppressed as early as 1870 . Eventually, the consumption tax had to be restored, first in order to finance the local and provincial councils, and then as a revenue for the National Treasury in 1874.

\section{INFLUENCES ON ECONOMISTS IN THE INCOME TAX DEBATE}

All MPs taking part in the debate on income tax shared the common economic thought framework of classical liberalism, differences lying only in their degree of attachment to this body of ideas. The majority of classical economists dealt with the problem of taxation, although their judgements on the ideal tax structure were much less unified than on other matters. Many of them made statements on the hypothetical ideal taxation system and its characteristics only to acknowledge that, in the end, fiscal policy should be built on feasible taxes depending on national economic structures and fiscal traditions. Spanish contemporaneous economic writers were not an exception; their works explained the ideal characteristics of a nation's fiscal organisation (nearly all of them following Smith's fiscal principles) and then considered their applicability to Spanish circumstances. There are no direct quotations from the debate, but the ideas that appeared in Parliament can be found in the authors of the $19^{\text {th }}$ century Spanish liberal tradition: Flórez Estrada, Jaumeandreu, Canga Argüelles, Pastor, Colmeiro, etc. Some MPs (particularly the economistas) knew the main liberal economic works, through direct readings (mostly French works), translations or journals such as the Journal des économistes. As for other MPs in the debate, it is safe to say that they would have known at least the main Spanish economic works of the $19^{\text {th }}$ century.

Both sides in the debate had plenty of sources to sustain their respective positions; they could even resort to the same authors to defend and attack the

${ }^{41}$ DSCC (105, Appendix 1, pp. 1-3). However, it is important to remark that the economistas main battlefield was the question of customs duties. Rodríguez was probably the most combative economista in Parliament and the closest to theoretical reasoning. He supported Figuerola in his reform strategy, although he desired broader measures for trade liberalisation. In fact, this matter opened a fissure among membership of the Escuela economista (see DSCC 105, p. 2877).

${ }^{42}$ The outcome of the poll was ninety-one votes for and fifty-six against (DSCC 110, pp. 3165-3168). 
income tax. MPs supporting the income tax (once again especially sympathisers of the Escuela economista) defended the position that liberal principles were the driving force behind the income tax and the basis of a modern tax system. The idea that a sound fiscal system should tax personal income appeared in works by Flórez Estrada (1828, pp. 304-314), Canga Argüelles (1833, pp. 48-52), Jaumeandreu (1816, pp. 297-301), Del Valle (1842, p. 493), López Narváez (1856, pp. 50-54), and Pastor (1856, I, pp. 220-225; II, pp. 2-15). However, some of these authors considered this to be theoretically desirable but unfeasible in practice. MPs who were detractors of the income tax did not deny its suitability and soundness, but put forward applied fiscal literature to discard its establishment in Spain. In this regard, they also had a good amount of credited economic works to sustain their positions. Leaving aside the idea of restraint in public expenditure, a precept accepted by all liberal authors, the lines of reasoning these MPs used matched the fiscal thought of many Spanish authors, who supported the doctrine of the income tax but believed that it was very difficult to establish in Spain: Alcalá Galiano, for instance, highlighted the difficulty of ascertaining individuals' income. Flórez Estrada stated that a single tax on income would be the ideal tax; however, the lack of reliable information on income made it unfeasible. An efficient taxation system should include a variety of taxes. Colmeiro shared the opinion that the problem was assessing individual wealth, which had to be done either through imperfect systems or inquisitorial enquiries. Domenech also believed that the impossibility of assessing income rendered it impracticable to set up a single tax on net income, the scientific ideal. Toledano defended a system consisting of several direct taxes on different sources of income (Alcalá Galiano 1788, pp. 66-67; Flórez Estrada 1828, pp. 304-314, 331-332; Colmeiro 1873, pp. 464-472; El estudiante de Barcelona 1869, pp. 235-240; Toledano 1963, pp. 593-594, 600-603) ${ }^{43}$.

Figuerola's first project is particularly interesting. Although he claimed that he was inspired by the British income tax, both taxes were formally quite different. Nevertheless, Figuerola's specific proposal had some precedents, which he probably knew, in that authors were aware that taxing overall incomes entailed major difficulties. Smith, in the Wealth of Nations, conceived the capitation tax not as a simple poll tax, but on a more complex basis, as a levy on all revenues accruing to the individual ${ }^{44}$. However, assessment

\footnotetext{
43 Other authors had more peculiar suggestions. For instance, Miranda y Eguía (1869, pp. 44-64) suggested a fiscal system grounded on a direct «real-personal» single tax that would combine two fiscal bases: the capital (for the real tax) and the individual (for the personal tax). The personal tax would be a capitation tax with low tax rates. Payment of this tax would confer citizenship rights on individuals. The idea of linking tax payment to civil rights was supported by Figuerola.

${ }^{44}$ Smith's judgement of this tax was not benevolent. Capitation taxes, when attempts were made to make them proportional to the fortune or revenue of each contributor, became arbitrary and uncertain, because an individual's fortune varied from day to day, and therefore an intolerable inquisition procedure was required to assess the tax base with accuracy (Smith 1976, pp. 867-869).
} 
difficulties as well as dislike for indirect taxation seem to have caused him to support a tax on housing (Shehab 1953, p. 33). In fact, Smith (1976, pp. 840-842) considered that, concerning expenditure, housing rent was the best indicator of a taxpayer's wealth ${ }^{45}$. In 1778, Britain adopted a tax on housing rent, taking the annual rent as a manifestation of ability to pay (instead of the number of windows or hearths). When establishing it, the difficulties of devising an equitable tax and of ascertaining the individual's real ability to pay was admitted. McCulloch (1975, pp. 250-251) also praised a tax on housing rent, highlighting its advantages in terms of assessment and the difficulty of tax evasion, whereas J. S. Mill also believed that housing was, in general, a good indicator of income ${ }^{46}$. Passy, a disciple of Bastiat, is an interesting case. He was an enthusiastic supporter of the single income tax, but, in order to assess net income, he believed that the most secure indicator was housing rent, as this was an expense that reflected citizens' wealth and income accurately (El estudiante de Barcelona 1869, pp. 235-240) ${ }^{47}$. Some Spanish authors also recommended a tax on housing rent. Alcalá Galiano (1788, pp. 61-62), following Smith, supported a tax on «the rent of the houses or of any ground» as the most convenient form of tax. Muchada (1847, II, pp. 13-14), in his 1847 handbook, proposed the replacement of taxes on consumable commodities with a tax on housing rents in the form of a capitation that actually resembled Figuerola's 1868 personal tax scheme quite closely. Figuerola's tax was also reminiscent of the Contribution personelle-mobilière, one of the four direct taxes created in France after the Revolution. It was based on several items, the main one being housing rent. General and local councils fixed quotas for every town, whereas local assessors were in charge of allocating the individual tax burden (Schnerb 1973, p. 73; Piketty 2001, p. 235). However, an essential difference was the generality of Figuerola's personal tax, one of its key characteristics.

\section{THE BRITISH INCOME TAX MODEL}

By the time income tax was being debated in Spain, it had already had a long history in Britain. Many related issues had been discussed and tested

${ }^{45}$ The inequality with which it might affect the residents of a house would depend on the proportion of expenditure individuals assigned to housing rent, higher for the wealthy and lower for the poor. Smith considered that the tax on housing rent was of the same nature as a tax on any other sort of consumable commodity, a comparison that frequently appeared in the parliamentary debate.

46 Mill (2000, p. 836) dismissed one core argument against this tax (which was raised in the 1869 debate): the idea that large poor families were likely to rent big houses, this tax being a regressive tax on poverty. Mill said that in such cases, the tax would act as a luxury tax on procreation, fostering restraint. Nevertheless, he accepted the exemption of a minimum of subsistence.

${ }^{47}$ I have not been able to find Passy's original quotation. In 1901, he published an article against a synthetic income tax, preferring a diversity of taxes on all single incomes, or a schedule income tax, like the British one. Passy (1901, pp. 50-53). 
(tax bases, graduation, differentiation of incomes, collecting procedures, etc.). First instituted in 1799 by Pitt during the Napoleonic Wars, it was repealed in 1816 and re-established in 1842 by Robert Peel ${ }^{48}$. The quest for a durable method of fair allocation of the tax burden is to be found behind Pitt's attempt. Income tax would be a crucial feature of Victorian fiscal constitution, becoming a significant characteristic of British identity and a mark of the secure relationship between state and individuals, in contrast with continental states. However, O'Brien (2004: 301) believes that «it found little enthusiastic support among the classical economists» ${ }^{49}$. The structure of the income tax restored by Peel was that devised by Addington in 1803 . Pitt's previous 1799 model required the assessment of taxpayers' total income, which was then taxed as a whole. Addington divided the tax into five different schedules corresponding to diverse types of income ${ }^{50}$.

Such a complex structure was not to be found in Figuerola's project or in the Budget Commission's version. Figuerola's personal tax procedures were completely different from those of British income tax sharing, at most, two core features: personalisation and generality. Figuerola designed a tax which was direct, personal, general, and which was levied on individuals' incomes assessed through a simple external indicator that was not difficult to check. Fairness was one of its problems; it could be regressive for large families with low incomes. Concerning collection procedures, the system of quotas prevented real proportionality. However, this was probably the only feasible system as there were no reliable statistics on national, provincial or local wealth $^{51}$.The personal tax designed in the Budget Commission was closer to Pitt's model, as it taxed individual income as a whole. The taxable base was personal income assessed through personal declaration after payments corresponding to other direct taxes had been deducted ${ }^{52}$. The quota system to

48 The debate on the assessed taxes at the end of the $18^{\text {th }}$ century is behind the 1799 income tax. A fiscal system able to provide some equilibrium between taxation on general consumers and welloff people required the setting up of a new fiscal tool that incorporated direct assessment of income. Shehab (1953, pp. 35-45). As in the Spanish case, the rigidity of traditional taxes, which were unable to tax the new activities that economic progress was setting off, was a general concern in Britain. Daunton (2001, p. 43).

49 There was a broad consensus that this sort of tax was justified only in emergency circumstances. It should be proportional, never progressive.

50 This classification of incomes proved very convenient, for the yields showed great improvement (Daunton 2001, pp. 183-185; Sabine 1966, p. 35). Peel's old system was a lump-sum income tax, where each individual had to make a return of his entire income. This system would be adopted later by some continental states, such as Prussia (Seligman 1913, pp. 485-486).

51 Moreover, the classification of towns according to their population in order to establish the tax bill regardless of real wealth was unfavourable to poor people living in large towns. As some MPs argued, Figuerola's personal tax could be considered not as a capitation tax, but as a tax levied on residents, for the head of the family was responsible for the payment of the share of all the household individuals.

52 The word used to define the object of taxation was «haber». Despite its vagueness, I think it can be assimilated into «income». Nevertheless, the term «haber» was never precisely defined. It would not include interest returns from public securities, as they had been excluded from taxation 
allocate tax shares subsisted, which in fact cancelled the equality principle. An interesting feature was that this tax, unlike the British version, made a rough differentiation between temporary and permanent incomes in the interest of tax justice ${ }^{53}$. A feature that both Figuerola's model and the Commission's income tax shared with the British tax was the involvement of taxpayers in the procedures to solve complaints addressed to the Treasury, an attempt to "create in our country free peoples' habits», as the decree of 12 October stated. Regarding the administration of the personal tax, Figuerola's expectations that its costs would be much lower than consumption tax were well grounded; the British example showed that, in the mid-19 $9^{\text {th }}$ century, the bureaucracy required for income tax had been reduced substantially.

Income tax was eventually accepted in Britain, but not without criticism. Pitt's bill faced tough opposition in the Commons, MPs' complaints being not very different from what would be heard in the Spanish Parliament 70 years later. Income tax was established as an emergency measure; hence, once the war was over, it was difficult to justify its continuity. Peel re-established it in 1842 on a temporary basis, as a tool to fight budget deficit, expecting that it would foster industry and trade and reduce the cost of living ${ }^{54}$. However, criticisms were fierce: radicals and free trade supporters demanded a policy of retrenchment while they saw the tax as a threat to personal liberty. There were also advocates of establishing differentiation between the origins of income to overcome the unfair incidence of the tax. This latter debate lasted until the 1860s so that when Spain began to discuss personal tax, the British model was not yet fully established. It would not be until the last quarter of the century that it became consolidated as a permanent element of the fiscal system.

War circumstances in Britain were essential to the introduction of income tax in 1799. Levi (1988, pp. 137-144) put forward a suggestive theory that stresses an essential factor that contributed to its establishment: a widespread «quasi-voluntary compliance» of taxpayers with the income tax, without which transaction costs of managing the tax would have been too high. The British government managed to convince citizens that, despite the

\footnotetext{
(F'note continued)

during the debate. From the description of the bases of the tax, it is possible to infer that it could refer to other interest returns, salaries, wages and other remuneration for working, allowances and pensions.

53 Temporary incomes were considered at half their amount when assessing the tax bill. This allowance was introduced in order to take into account the circumstances of day labourers. Their precarious situation was denounced by opponents of the personal tax, as they believed that they would not be able to afford to pay it.

54 According to Daunton, Peel's manoeuvre aimed more at removing political tensions and reinforcing the government position than at raising revenues. He tried to maintain a process of political and social stabilization through a tax system neutral to vested interests and protecting property. This would be a means to stimulate economic growth. "The income tax was therefore intended to provide a temporary source of income to cover the transition from a regime of high duties and low yields to a dynamic economy based on low duties and high yields» (Daunton 2001, p. 80).
} 
fact that it represented a new burden and a major intrusion into privacy, this tax was necessary and would be well managed. This would not have been achieved without a contemporary evolution of representative institutions and citizens' control of government. This process took place in the framework of a relatively highly advanced economy with a well-developed and trained fiscal bureaucracy. In fact, a sound fiscal administration was crucial: the liberal principle of privacy excluded old inquisitorial proceedings, giving rise to a taxation system in which the tax burden was assessed through external indicators. Some of the income schedules allowed tax collection at source, a procedure that many considered as the key factor for the success of income tax after its re-introduction in 1842 and a safeguard against fraud. The rest of the revenue depended on the taxpayer's tax return and on the accuracy of control systems ${ }^{55}$.

Why did income tax not succeed in Spain? Certainly, there was a widespread admiration for the British income tax, and Figuerola's idea of promoting industrialisation and trade resembled that of Peel in 1842. However, extensive rejection of the tax, fiscal administration weakness and political matters contributed to its failure. British «quasi-voluntary compliance» was absent in the Spanish case. Figuerola's personal tax was rejected by most of the population (to whom it was merely a replacement for consumption taxes) ${ }^{56}$. It was also rejected by local authorities, unable and unwilling to collect it, as reports addressed to the Parliament witnessed ${ }^{57}$ and by the majority of MPs, who thought its foundations were defective. The Budget Commission's income tax bases were too ambitious and exceeded the capabilities of the Spanish administration, too inefficient and deprived of statistical information for this tax to succeed ${ }^{58}$. Moreover, as some MPs underlined, there was no taxpaying culture in Spain, and fraud was widespread. The defence many MPs made of this unrealistic project shows ingenuity and doctrinaire positions, with which Figuerola's pragmatism clashed. Together with these elements, the political agenda of the new government was also significant; this may be seen by comparing the success of the tariffs policy with the failure of income tax. Trade liberalisation through a reduction in customs duties was a top priority on the political agenda. This had been the main concern of the Escuela economista during the previous years and was continuously present in public debate. Despite opposition, this bill was passed without major difficulties, representing Figuerola's most important success. A tax on incomes was another of Figuerola's targets in fiscal reform; however, this had been included in the

55 Daunton (2001, p. 186) states that in 1855-1856 the tax revenue under schedules A, C and E was collected at source and represented 63.5 per cent of the net revenue from income tax that year.

56 In fact, one of the main revolutionary mottos was «Down with consumption taxes!»

57 On the difficulties of collecting Figuerola's tax, see DSCC (26, p. 784). The flood of reports against it is in DSCC (40, pp. 794-795).

58 Some authors believe that this was one of the key factors behind the failure of Figuerola's economic reforms (see Comín 1988, p. 591; Martín Niño 1972, p. 218). 
agenda after the juntas' abolition of consumption taxes. It also then became a policy priority because its revenues were indispensable for the Treasury. Contrary to tariff reform, there had been no previous process of debate and diffusion of its advantages to public opinion, which meant that it was hard to understand and difficult to accept. In any case, Figuerola became personally involved with the income tax. At the beginning of the debate, he declared that he linked his continuance in the cabinet to Parliament's passing of the personal tax bill (he had done the same only concerning the tariff reform) ${ }^{59}$. Figuerola's model of income tax might have had a chance of success but the tax on incomes finally passed was unfeasible.

\section{CONCLUDING REMARKS}

Surprisingly, Figuerola's tax and the Budget Commission's reformed version have, in general, been ignored as attempts to set up an income tax in Spain. Moreover, they seem to have been soon forgotten as contemporary fiscal handbooks ignored them or simply mentioned them in passing ${ }^{60}$. Later, only Ballesteros (1933) and Sardá (1944) considered Figuerola's project as a precedent of income tax. In general, authors have been quite unsympathetic, pointing out its flaws ${ }^{61}$. A recent exception is Comín (2010: 230), who accurately noted that this tax was "too advanced for its time», stressing that "had it been consolidated, Spain would have pioneered the establishment of income tax".

Evidence suggests that this was a serious attempt to establish a tax on income in Spain. Its point of departure was accidental, but Figuerola became engaged with the introduction of the new personal tax. On the one hand, the revenues formerly provided by consumption excises were essential (therefore, a new tax was needed), but on the other hand, he believed in the longterm benefits that the introduction and development of a tax on incomes could bring to the Spanish tax system and the nation's economy in general. Figuerola's economic thought had much to do with this process. His faith in economic classical liberal principles (shared by the membership of the

$59 \operatorname{DSCC}(105$, p. 2854).

60 Miranda y Eguía (1869, p. 143) was the only author to mention Figuerola's tax briefly, with quite a critical judgement. He said that it was a capitation tax that was impossible to collect. He did not mention the Budget Commission tax. Piernas Hurtado (1900-1901, p. 133), in the most praised finance book of the century, also mentioned Figuerola's tax as a mixture of poll tax and tenancy tax. He did not refer to the second version. This seems to prove that the final income tax was hardly relevant.

${ }^{61}$ For instance, Artola (1986, p. 329) was extremely critical of Figuerola's tax. Martín Niño (1972, pp. 212-213) remarked on the inaccuracy of the tax base. It is symptomatic that these attempts were not even mentioned in the journal De Economía's 1955 special issue on the history of income tax in Spain. Costas believed that the crucial point was whether it would not have been more suitable to create new taxes on particular flows of incomes and merge them later in an income tax (Costas 1988, pp. 76-77). 
Escuela economista, the intellectual elite that was the main force behind the presence of economic thought in the political sphere), made him argue that their implementation would foster economic development and lead the country into the group of advanced European nations. Income tax, the ideal tax according to liberal political economy, would then be a keystone in the economic modernisation of the country. The British example showed the way. In line with his gradualist strategy and forecasting difficulties both of acquiescence and execution, Figuerola designed an imperfect, but plausible, income tax grounded on fiscal scientific principles.

Figuerola's tax raised major concern in Parliament (and also among economistas), provoking discussions on the form it should take. Eventually, the Parliamentary Budget Commission reformed its bases and turned it into a pure income tax, to be debated in the chamber. Two positions confronted each other. On the one side, income tax supporters defended the government's long-term plan to foster economic development, in which income tax was an essential part, as the British case had proved. On the other side, the opposition acknowledged its doctrinal soundness, but considered it impossible to set up in Spain. Their only alternative was cutting expenditure. Economic ideas played an important role in the debates. Both positions shared a common background, economic liberalism, whose principles they appealed to in their discourses. Differences lay in each party's considerations about how to apply theory effectively.

The debate showed that a considerable number of MPs had a good degree of economic competence, displaying their knowledge of economic liberal doctrines and policies put into practice in other countries. Economic debates aided the development of the process of institutionalisation of political economy in Spain. The expansion of political economy in society was considered (particularly, but not exclusively, by the economistas) as something to be encouraged, and Parliament was an instrument in this regard as discussions were widely publicised. As Ruiz Gómez, MP, said, complaining that the population should have a better awareness of economic issues, a deeper implication of MPs in fiscal debates would foster the spread of knowledge on these matters ${ }^{62}$.

The government plan to establish an income tax in Spain did not succeed with several causes interacting in this failure. Most of the population rejected a tax that came to replace the detested consumption taxes, abolished by the Revolution. The authorities were also very reluctant to apply the tax and the eventual bases of the income tax made it almost impossible to control by fiscal authorities (this leaves the doubt whether Figuerola's more feasible primitive bases would have had a better chance). There was also a factor connected to the political agenda; contrary to tariff reform, income tax rapidly became a political objective, without previous presentation and discussion in public opinion, which decreased its likelihood of being accepted.

${ }^{62} \operatorname{DSCC}(105$, pp. 2859-2860). 


\section{REFERENCES}

Alcalá Galiano, V. (1788): Sobre la necesidad y justicia de los tributos, fondos de donde deben sacarse y medios de recaudarlos. Segovia: Sociedad Económica de Segovia.

Almenar, S. (2000): «El desarrollo del pensamiento económico clásico en España», in E. Fuentes Quintana (ed.), Economía y economistas españoles, 4. La economía clásica. Barcelona: Galaxia Gutenberg, pp. 7-92.

Almenar, S. (2005): "Chair, Tribune and Seat: Spanish Economists in Parliament (1844-1923): An exploration», in M. Augello, and M. Guidi (eds), Economists in Parliament in the Liberal Age (1848-1920). Aldershot: Ashgate, pp. 75-102.

Almenar, S., and Lluch, E. (2000): «Difusión e influencia de los economistas clásicos en España», in E. Fuentes Quintana (ed.), Economía y economistas españoles, 4. La economía clásica. Barcelona: Galaxia Gutenberg, pp. 93-170.

Almodovar, A., and Cardoso, J. L. (2005): "Political Economy in Portuguese Parliamentary Debates (1820-1910)», in M. Augello, and M. Guidi (eds), Economists in Parliament in the Liberal Age (1848-1920). Aldershot: Ashgate, pp. 27-47.

ARtola, M. (1986): La hacienda del siglo XIX: progresistas y moderados. Madrid: Alianza Editorial.

Augello, M., and Guidi, M. (eds) (2002): La scienza economica in Parlamento 1861-1922. Una storia dell' economia politica dell' Italia liberale I. Milano: Franco Angeli.

Augello, M., and Guidi, M. (eds) (2003): Gli economisti in Parlamento. Una storia dell' economia politica dell' Italia liberale II. Milano: Franco Angeli.

Augello, M., and Guidi, M. (eds) (2005a): Economists in Parliament in the Liberal Age (1848-1920). Aldershot: Ashgate.

Augello, M., and Guidi, M. (2005b): «The Italian Economists in Parliament from 1860 to 1922: A Quantitative Analysis». European Journal of History of Economic Thought 12 (2), pp. 279-319.

Ballesteros, P. (1933): La contribución general sobre la renta en España. Madrid: Editorial Revista de Derecho Privado.

Bastien, C., and Cardoso, J. L. (2009): "Uses and Abuses of Political Economy in Portuguese Parliamentary Debates (1850-1910)». History of Economic Ideas XVII (3), pp. 41-57.

Cabrillo, F. (2000): «Laureano Figuerola o el reformismo economista», in E. Fuentes Quintana (ed.), Economía y economistas españoles, 4. La economía clásica. Barcelona: Galaxia Gutenberg, pp. 483-497.

CANGa Argüelles, J. (1833): Elementos de la ciencia de la Hacienda. Madrid: D.J. Palacios.

CARdoso, J. L. (2007): «Economic and Financial Debates in the Portuguese Parliament (1821-1910): Outcome of a Research Project». e-Journal of Portuguese History 5 (2), pp. 1-19.

Coats, A. W. (1993): «Introduction», in A. W. Coats (ed.), The Sociology and Professionalization of Economics. British and American Economic Essays, vol. II. London: Routledge, pp. 1-7.

Colmeiro, M. (1873): Principios de Economía Política. Madrid: Fermín Martínez García.

Comín, F. (1988): Hacienda y Economía en la España contemporánea (1800-1936). Madrid: Ministerio de Economía y Hacienda.

Сомín, F. (2010): "Public Finance and the Rise of the Liberal State in Spain», in J. L Cardoso, and P. Lains (eds), Paying for the Liberal State. The Rise of Public Finance in Nineteenth-Century Europe. New York: Cambridge UP, pp. 214-250.

Costas, A. (1982): Política económica y reforma liberal (1868-1874). Barcelona: Universitat de Barcelona. 
Costas, A. (1988): Apogeo del liberalismo en «La Gloriosa». La reforma económica en el Sexenio liberal (1868-1874). Madrid: Siglo XXI de España.

Costas, A. (2000): «Industrialización y cuestión arancelaria en España. Reflexiones en torno al liberalismo de Laureano Figuerola», in E. Fuentes Quintana (ed.), Economía y economistas españoles, 4. La economia clasica. Barcelona: Galaxia Gutenberg, pp. 459-482.

Daunton, M. J. (2001): Trusting Leviathan: The Politics of Taxation in Britain, 1799-1914. Cambridge: Cambridge University Press.

Diario de Sesiones de las Cortes Constituyentes (DSCC) 1869-1871, Madrid.

Estapé, F. (2001): La reforma tributaria de 1845. Madrid: Instituto de Estudios Fiscales.

EstapÉ, F. (2006): Tres grandes economistas catalanes y la Real Academia. Madrid: Real Academia de Ciencias Morales y Políticas.

Estudiante de Barcelona, El (1869): Apuntes de Economía Política, tomadas de las esplicaciones (sic) del catedrático de la propia asignatura en la Universidad de Barcelona. Barcelona.

Fetter, F. W. (1975): «The Influence of Economists in Parliament on British Legislation from Ricardo John Stuart Mill». Journal of Political Economy 83 (5), pp. 1051-1064.

Fetter, F. W. (1980): The Economists in Parliament, 1780-1868. Durham, NC: Duke University Press.

Flórez Estrada, Á. (1828): Curso de economía política. London: D.M. Calero.

Fuentes Quintana, E. (1990): Las reformas tributarias en España. Teoría, historia y propuestas. Barcelona: Crítica.

Gambles, A. (1999): Protection and Politics: Conservative Economic Discourse, 1815-1852. Woodbridge, Suffolk: The Royal Historical Society, The Boydell Press.

González de la PeÑa, Á. (1891): Estadística de los Presupuestos Generales del Estado, 1850 a 1890-91. Madrid: Imprenta de la Fábrica Nacional del Timbre.

Gordon, B. L. J. (1976): Political Economy in Parliament, 1780-1823. London: Macmillan.

Grampr, W. (1987): «How Britain Turned to Free Trade». Business History Review 61 (1), pp. 86-112.

HARrIS, R. (1997): «Political Economy, Interest Groups, Legal Institutions, and the Repeal of the Bubble Act in 1825». The Economic History Review 50 (4), pp. 675-696.

JANÉ Solà, J. (coord.) (2003): Laureà Figuerola i la pesseta. Barcelona: Societat Catalana d'Economia.

JaUmEANDReu, E. (1816): Rudimentos de economía política. Barcelona: Antonio Brusí.

Levi, M. (1988): Of Rule and Revenue. Berkeley: University of California Press.

Llanta, S. (1869): Los Diputados pintados por sus hechos: Colección de estudios biográficos sobre los elegidos por el sufragio universal en las constituyentes de 1869. Madrid: Labajos y Compañía.

López NaRváez, J. (1856): Tratado de Hacienda pública o exposición de las teorías de esta ciencia con aplicación a la legislación española. Madrid: Pedro Montero.

Luzstig, M. (1995): «Solving Peel's Puzzle. Repeal of the Corn Laws and Institutional Preservation». Comparative Politics 27 (4), pp. 393-408.

MarTín Niño, J. (1972): La Hacienda Española y la Revolución de 1868. Madrid: Instituto de Estudios Fiscales.

Mateo del Peral, D. (1974): La Banca española en la restauración II. Datos para una historia económica. Madrid: Banco de España.

Mcculloch, J. R. (1975 [1863]). A Treatise on the Principles and Practical Influence of Taxation and the Funding System. Edinburgh: Scottish Academic Press.

MILL, J. S. (2000 [1848]). Principles of Political Economy with Some of Their Applications to Social Philosophy. London: Routledge. 
Miranda y Eguía, M. (1869): Revolución financiera de España. Madrid: Pardo y Juste.

Muchada, J. P. (1847): La Hacienda de España y modo de reorganizarla. Madrid: Imprenta del Diccionario Geográfico.

O'Brien, D. P. (2004): The Classical Economists Revisited. Princeton: Princeton University Press.

Passy, F. (1901): «L'impot progressif et l'impot sur le revenu», in Pages et Discours. Paris: Guillaumin, pp. 45-54.

Pastor, L. M. (1856): La ciencia de la contribución. Madrid: Carlos Bailly-Baillière.

Perdices, L.; Reeder, J., and Arribas, V. (2003): Diccionario de Pensamiento Económico en España (1500-2000). Madrid: Síntesis.

Piernas Hurtado, J. M. (1900-1901). Tratado de Hacienda Pública y examen de la española. Madrid: Victoriano Suárez.

PiketTy, T. (2001): Les hauts revenus en France au XXe siecle : inegalites et redistributions, 1901-1998. Paris: B. Grasset.

Román, R. (2003): La escuela economista española. Sevilla: Universidad de Sevilla.

SABINE, B. E. V. (1966): A History of Income Tax. London: Allen \& Unwin.

SAN Julián, J. (2008): "The Spread of Economic Thought in the Parliament and the Institutionalisation of Political Economy in Spain, 1868-1900». Firenze: European University Institute, $\mathrm{PhD}$ dissertation.

SARDÁ, J. (1944): "Apéndices sobre la Hacienda española», in K. T. Eheberg (ed.), Principios de Hacienda. Barcelona: Gustavo Gili.

Schnerb, R. (1973): Deux siecles de fiscalite française XIXe-XXe siècle. Histoire, économie, politique. Paris La Haye: Mouton.

Schonhardt-Bailey, C. (2003): «Ideology, Party and Interests in the British Parliament of 1841-47». British Journal of Political Science 33 (4), pp. 581-605.

Schonhardt-Bailey, C. (2006): From the Corn Laws to Free Trade: Interests, Ideas, and Institutions in Historical Perspective. Cambridge and London: MIT Press.

Seligman, E. R. A. (1913): L'impôt sur le revenu. Paris: Giard.

Serrano, J. M.; Sánchez Hormigo, A., and Malo, J. L. (2001): «Las críticas a la economía clásica», in E. Fuentes Quintana (ed.), Economía y economistas españoles 5. Las críticas a la economía clásica. Barcelona: Galaxia Gutenberg, pp. 7-124.

Sheнав, F. (1953): Progressive Taxation: A Study in the Development of the Progressive Principle in the British Income Tax. Oxford: Clarendon Press.

Sмiтн, A. (1976 [1776]). An Inquiry into the Nature and Causes of the Wealth of Nations. Oxford: Clarendon Press.

Toledano, E. (1963 [1859-1860]). Curso de Instituciones de Hacienda Pública en España con arreglo a las últimas explicaciones y programa vigente en la Universidad Central. Madrid: Instituto de Estudios Políticos.

Valle, E. M. d. (1842): Curso de Economía Política. Madrid: Imprenta del Colegio Nacional de Sordomudos. 